\title{
The Relationship between Doctor and Patient as an Indicator of the Level of Trust in Medical Care
}

\author{
Katarzyna Pawlikowska - Łagód $^{1} \&$ Magdalena Suchodolska ${ }^{2}$ \\ ${ }^{1}$ Cathedral and Department of Humanities and Social Medicine, Medical University of Lublin, Poland \\ ${ }^{2}$ Medical University of Lublin, Poland \\ Correspondence: Katarzyna Pawlikowska - Łagód, Cathedral and Department of Humanities and Social Medicine, \\ Medical University of Lublin, ul. Chodźki 7, 20 - 093 Lublin, Poland.
}

Received: April 9, 2021 Accepted: May 27, 2021 Online Published: May 31, 2021

doi:10.5539/gjhs.v13n7p56

URL: https://doi.org/10.5539/gjhs.v13n7p56

\begin{abstract}
Communication between the doctor and the patient is one of the most important elements affecting the treatment process. The trust, which determines the patients' health attitude and their implementation of medical recommendations, is built by maintaining an appropriate doctor-patient relationship. A trusting patients demonstrate better mental and physical well-being, obtain better diagnostic results, use preventive healthcare services more frequently, and show greater confidence in the overall health system. Nevertheless, in order for the patients to exhibit such behaviors, they must trust the physician, which is influenced by many important issues: the maintenance an appropriate doctor-patient relationship, the patients' hope, the prevailing opinion about the physician as well as stereotypes about the medical profession (including age, gender, professional experience, professional and scientific title). This paper presents different models of the doctor-patient relationship and how each of them affects the level of trust in the discussed relationship. In addition, it is described how stereotypes about medical personnel influence the trust among patients. All information included in the study are based on the available literature.
\end{abstract}

Keywords: communication, trust, trust in the doctor, stereotypes

\section{Introduction}

The doctor-patient relationship is constructed, at least in part, by doctor-patient communication. In this case, communication is important to learn about the patient's disease symptoms, make an appropriate diagnosis, make recommendations and monitor treatment. This is so in throughout medicine (McCabe \& Healey, 2018). The doctor-patient relationship is a multidimensional concept that begins when a patient consults a doctor, then strives for compliance with medical recommendations (Qiao et al., 2019).

Beginning the consideration of the doctor-patient relationship, it should be noted that it is a social phenomenon based on social relationships. In every such interaction, there are dependencies that result from the mutual influence of people on each other; they may take functional, causal and structural forms and occur in a symmetrical (differentiated power between interlocutors) and asymmetrical way (domination of one of the partners). The doctor-patient relations in the social dimension constitute a specific system of certain interactions that are a consequence of, among other things, the patient's health condition.

It should be remembered that this relationship is a key element of health care despite the development of medical techniques, healthcare systems and technological progress (telemedicine, electronic prescriptions). Moreover, there have been many changes in models of the doctor-patient relationship and their ethical implications over the years, however, trust in face-to-face meetings with medical staff has been recognized as having a central role (Song et al., 2020).

The relationship between the doctor and the patient is considered to be multidependent because, among others, the social position of a physician is completely different from that of a patient, it results from the characteristics assigned to physician's profession and authority to make decisions regarding the patient's health situation (Tobiasz-Adamczyk, 2002).

The literature on the subject distinguishes many models of the doctor-patient relationships including: model developed by Talcott Parsons, paternalistic model, cooperative model and system-partner model. 


\section{Doctor-Patient Relationship Model by Talcott Parsons}

The theory presented by Parsons (1951) is referred to as the functional model of the doctor-patient relationship. It takes an asymmetrical form and is one of the main paternalistic models. In this conception, the physicians, due to the acquired competences, have the right to complete and authoritative decisions about the patients in a situation of illness, both physical and mental. The doctors' authority is the result of strong social legitimacy, acquired knowledge and skills. In their work, the physicians should be guided by emotional neutrality, universalism and the specificity of their profession. This model is characterized by the fact that it is the doctor who exclusively decides about the treatment process of the patient, while the patient has the passive role (Czerska, 2016).

The patient is solely expected to focus on compliance with the presented treatment requirements (Zembala, 2015). It is specified that in this model, the patients' sense of security is to be provided only by medical knowledge and professional skills of the doctors. Additional interpersonal skills are not required from the physicians in order to deepen the relationship with the patients (Jarosz et al., 2012). In the model of communication discussed above, the trust between the doctors and the patients may be to some extent compromised. Through the authoritative way of working of the doctors, the patients may experience lower value, social position and being dominated by the physicians. Lack of communication, only a pure biological approach to the disease may cause an unfavorable image of the doctors and thus a lack of trust.

\section{Paternalistic Model of the Doctor-Patient Relationship}

There is another, paternalistic model of communication in the relationship between the doctor and the patient. It has its source in the biomedical paradigm; it is characterized by treating a person as a machine, and the role of the doctors is limited to eliminating disturbances in its functioning (Zembala, 2015).

The position of the patients has to some extent changed compared to the previous model. Despite the fact that it is still passive, the role of the patients has been exposed in a certain way, as the doctors enter into an emotional relationship with them, also taking into account their families (Nowina-Konopka, 2016). The emotional bond that is created serves to obtain information from the patients to facilitate appropriate diagnosis and treatment, while the patients obtain information that motivate adherence to treatment. An important point is that in this concept there is a two-way flow of information, despite the subordinate role of the patients (Jarosz et al., 2012).

However, the paternalistic model has been widely criticized in medicine as a result of its authoritarian approach to the patients. Nevertheless, there is already a higher level of trust between the doctors and the patients than in the Parsons' model, although, due to the still limited flow of information, this level may still be low.

\section{Cooperative Model of the Doctor-Patient Relationship}

Referring to model of two-way communication, attention should be paid to the concept of cooperative (partner) communication. This model originates from the sociomedical paradigm, where the disease is understood in terms of mental, biological and social issues, and the relationship between the mind and body is observed. The development of medical technologies and general interest in health and disease, associated with this model, contributed to the flourishing of the cooperative system (Zembala, 2015).

This model is characterized by the fact that the main attention is focused on the patients and, to a greater extent than in the previous models, also includes their families. There is mutual cooperation between the doctors and the patients and between the doctors and the patients' families (although being outside the social system of the family). An emotional bond is established, despite maintaining a certain distance (Jarosz et al., 2012), both parties are willing to cooperate.

The patients seek help and the doctors, due to their competences and a kind of authority, paying attention to the observations and personal perceptions of the patients, provide it (Szasz \& Hollender, 1956). In this model, a high level of trust in medical personnel may appear, it results mainly from the bilateral relationship and the bond that is created between the doctors, the patients and the patients' families.

\section{The System-Partner Model of the Doctor-Patient Relationship}

The last model is the system-partner communication model. In this system, doctors are defined as partners, because they are involved not only in the therapeutic process but also in interpersonal and social relations with patients. The physicians support the patients at every stage, from diagnosis to the last stage of treatment. They identify with both the patients and patiens' families, are focused on dialogue and identification of patients' health and emotional problems (Nowina-Konopka, 2016), help to undertake pro-health behaviors, motivate to follow treatment recommendations.

In this model, the patients' disease-related experiences provide reliability and valuable clues for diagnosis and 
further treatment (Szasz \& Hollender, 1956). The level of trust between the doctors and the patients in this model is the highest of all those described. It is influenced by the doctors' attitude to the patients and their families, their openness and reaction to every element of the therapeutic process. The patients receive a sense of security from the doctors and also a feeling that at each stage of treatment their suggestions, opinions and decisions are respected.

\section{Stereotypes in the Doctor-Patient Relationship}

Correct use of communication with the patients by medical personnel is the basis for the development of an appropriate level of trust towards each other. Doctors who are open to the needs and expectations of the patients treat them not as passive persons but as partners in the process of treatment. Nowadays, when patients are aware of their health and the availability of medical care services, they choose the representatives of the medical profession who are most trustworthy. Patients want to participate in the process of diagnosis, treatment and recovery, which in itself creates a certain interaction between them.

Aspects that will be important in building trust in relation to communication between the doctors and the patients include physicians' body language and verbal communication issues. It is estimated that the recipients of the message (the patients) are mainly influenced $(55 \%)$ by the body language of the senders - the doctors (posture, eye contact, facial expression, touch, gestures and other body movements, physical appearance, distance to the patients) and by the way the doctors relate to the patients (38\%) (vocabulary, simplicity in communication, empathy, perception and reaction to the message, accuracy and speed of speech) (Maciagg, 2008).

The literature on the subject identifies the following features of proper doctor-patient communication:

- Individual approach to the patients,

- Credibility, professionalism,

- Openness, kindness, empathy,

- Active listening and no judgment,

- Comprehensibility, simplicity of communication,

- Learning about the patients' needs, meeting them,

- Use of open-ended questions,

- Encourage the patients to use questions,

- Explaining problems in a clear way,

- Using appropriate vocabulary,

- $\quad$ Appropriate use of silence (Stangierska \& Horst-Sikorska, 2007).

The trust in medical personnel is shaped not only by the quality of communication between the doctors and the patients, but also by factors related to stereotypes concerning them (e.g. age, gender, professional experience, professional and scientific title). In the literature there is no unequivocal information that would determine whether patients trust female or male doctors and whether trust is aroused by the doctors with long or short professional experience. This trust depends on many factors: previous experience of patients, specialty performed and place of work of the doctors.

Some studies indicate that women are better doctors than men because they are characterized by greater accuracy and empathy, better verbal and non-verbal communication and the development of an appropriate emotional bond with the patients (Oxtoby, 2013). Female doctors focus more on details, their consultations are longer, they provide psychosocial advice but, on the other hand, they have more patients and are therefore less efficient (Patel, 2018). In contrast, other studies identify male doctors as more trustworthy because they are distinguished by better medical practice (Adudu \& Adudu, 2007).

The age of the doctors and thus their work experience, is also not a clear indicator of the level of trust. Nevertheless, many people are guided by these factors when choosing a particular specialist. Some patients decide to visit young doctors, claiming that they have up-to-date medical knowledge, as they graduated from medical studies relatively recently, are fluent in the latest diagnostic and therapeutic technologies. Other patients disqualify such doctors because, in their eyes, they do not inspire any trust, they only trust doctors with long work experience who have more professional and life experience. Another factor that can significantly affect trust towards doctors is their external appearance. Unfortunately, many patients judge doctors by appearance and first, often wrong, first impression. "He's a big, daring rugby fan, and when it comes to clinical practice, he prefers to cut rather than communicate with patients. She is cute and fluffy, with a constant smile and a little koala attached to her 
stethoscope. He is paternalistic, polite, with a passion for corduroy jackets (Rotel \& Hall, 2015, 273-274)." The descriptions refer to the surgeon, pediatrician and general practitioner. Nevertheless, not all patients would like to undergo a surgical procedure to be performed by a physician with an extended and muscular figure, as they may associate such a disposition negatively. Also the idealized image of pediatricians created by the media may in fact differ from the actual state. It is also important to note that physicians can be discriminated against on the basis of skin color and ethnic minority membership (Solnick et al., 2020). This is supported e.x. by studies in the United States in which is stated that physicians of minority and Asian origin were humiliated and discriminated by patients (Tedeschi, 2017). In addition, Wheeler's (2019) research indicates that medical staff faced rejection of concern, unpleasant comments, racist, sexist or homophobic epithets from patients and also jokes reflecting ethnic stereotypes (Wheeler, et al., 2019).

\section{Conclusion}

Defining the ideal doctor-patient relationship is quite difficult, as is defining the ideal doctor and patient. In the literature, we read that the ideal physicians should have adequate technical skills, good intentions towards patients, and correct interpersonal relationship characteristics (Borracci, et al., 2020). A proper relationship between the medical personnel and the patients is a key determinant to ensure the proper course of the medical process. "Doctor-patient trust is a global attribute of therapeutic relationship and usually includes supporting features such as communication, quality of medical services, and patients' satisfaction" (Du, et al., 2020). The effect that is achieved thanks to the exemplary communication between the doctors and the patients facilitates getting to know the patients, enhances trust and allows for a collaborative direction for the therapeutic process (Thomas, et al., 2020). The patients' trust in the doctors influences the perception of the disease, its acceptance and taking up the fight for the their health. Unfortunately, in Talcott Parsons' model of the relationship presented above, in which the physicians should be guided by emotional neutrality, the correct doctor-patient relationship cannot be stated. Despite the increased interaction between doctors and patients in the paternalistic model, it has been criticized in the literature due to the limited flow of information between them. It would seem that the last model, the system-partner model reflects the correct communication between doctors and patients. As the name suggests, this model is based on partnership, which is the basis of proper communication. Therefore, during the training of future medical personnel, special attention should be paid to this model of communication. The use of this model would increase the trust towards medical personnel, and thus reduce the economic costs associated with patients seeking diagnosis from different doctors in different institutions.

\section{Competing Interests Statement}

The authors declare that there are no competing or potential conflicts of interest.

\section{References}

Adudu, O. P., \& Adudu O. G. (2007). Do patiens view male and female doctors differently. East African Medical Journal, 84(4), 172-177. https://doi.org/10.4314/eamj.v84i4.9521

Borracci, RA., Álvarez Gallesio, JM., Ciambrone, G., Matayoshi, C., Rossi, F., \& Cabrera S. (2020). What patients consider to be a 'good' doctor, and what doctors consider to be a 'good' patient. Revista médica de Chile, 148(7), 930-938. https://doi.org/10.4067/S0034-98872020000700930

Czerska, I. (2016). Relacje lekarz - pacjent a wybrane teoretyczne modele relacji w kontekście dehumanizacji medycyny. Handel Wewnętrzny, 5(364), 37-45.

Du, L., Xu, J., Chen, X., Zhu, X., Zhang,Y., Ruiheng, W., Haoqiang, J., \& Zhou, L. (2020). Rebuild doctor-patient trust in medical service delivery in China. Scientifc Reports, 10(1), 21956. https://doi.org/10.1038/s41598-020-78921-y

Jarosz, M., \& Kawczyńska-Butrym, Z., \& Włoszczak-Szubzda A. (2012). Modele komunikacyjne relacji lekarz -pacjent-rodzina. Medycyna Ogólna i Nauki o Zdrowiu, 18(3), 212-218.

Maciąg, A. (2008). Komunikacja interpersonalna a jakość świadczeń zdrowotnych. Istota relacji lekarz-pacjent w medycynie: Studia i Materiały, Wydział Zarządzania, Uniwersytet Warszawski, 1, 125-133.

McCabe, R., \& Healey, GT. P. (2018). Miscommunication in Doctor-Patient Communication. Topics in Cognitive Science, 10(2), 409-424. https://doi.org/10.1111/tops.12337

Nowina- Konopka, M. (2016). Komunikacja lekarz- pacjent: Teoria i praktyka, Instytut Dziennikarstwa. Mediów i Komunikacji Społecznej Uniwersytet Jagielloński, Kraków.

Oxtoby, K. (2013). Do the classic specialty stereotypes still hold true for today's doctors? British Medical Journal, 
347. https://doi.org/10.1136/bmj.f7454

Patel, A. (2018). Does a doctor's age matter? Retreived August 15, 2020, from https://mumbaimirror.indiatimes.com/opinion/columnists/dr-altaf-patel/does-a-doctors-age-matter/articlesho $\mathrm{w} / 64263201 . \mathrm{cms}$

Patton, D. B., \& Blaine, T. W. (2001). Public issues education: Exploring Extension's role. Journal of Extension, 39(4).

Qiao, T., Fan, Y., Geater, A. F., Chongsuvivatwong, V., \& McNeil, E. B. (2019). Factors associated with the doctor-patient relationship: doctor and patient perspectives in hospital outpatient clinics of Inner Mongolia Autonomous Region, China. Patient preference and adherence, 13, 1125. https://doi.org/10.2147/PPA.S189345

Rittel, H. W., \& Webber, M. M. (1973). Dilemmas in a general theory of planning. Policy sciences, 4(2), 155-169. https://doi.org/10.1007/BF01405730

Roter, D. L., \& Hall, J. A. (2015). Women Doctors Don't Get the Credit They Deserve. Journal of General Internal Medicine, 30(3), 273-274. https://doi.org/10.1007/s11606-014-3081-9

Solnick, R. E., Peyton, K., Kraft-Todd, G., \& Safdar, B. (2020). Effect of physician gender and race on simulated patients' ratings and confidence in Their physicians: a randomized trial. JAMA network open, 3(2), e1920511-e1920511. https://doi.org/10.1001/jamanetworkopen.2019.20511

Song, Y., Luzzi, L., \& Brennan, D. S. (2020). Trust in dentist-patient relationships: mapping the relevant concepts. European Journal of Oral Sciences, 128(2), 110-119. https://doi.org/10.1111/eos.12686

Stangierska, I., \& Horst-Sikorska, W. (2007). Ogólne zasady komunikacji między pacjentem a lekarzem. Forum Medycyny Rodzinnej, 1(1), 58-68.

Szasz, T. S., \& Hollender, M. H. (1956). A contribution to the philosophy of medicine: the basic models of the doctor-patient relationship. AMA archives of internal medicine, 97(5), 585-592. https://doi.org/10.1001/archinte.1956.00250230079008

Tedeschi, B. (2017). 6 in 10 doctors report abusive remarks from patients, and many get little help coping with the wounds. STAT News. https://doi.org/10.1044/leader.PPL.22102017.18

Thomas, H., Best, M., \& Mitchell, G. (2020). Whole-person care in general practice: the doctor-patient relationship. Australian journal of general practice, 49(3), 139-144. https://doi.org/10.31128/AJGP-05-19-49502

Tobiasz-Adamczyk, B. (2002). Relacje lekarz-pacjent w perspektywie socjologii medycyny. Wydawnictwo Uniwersytetu Jagiellońskiego.

Wheeler, M., de Bourmont, S., Paul-Emile, K., Pfeffinger, A., McMullen, A., Critchfield, J. M., \& Fernandez, A. (2019). Physician and trainee experiences with patient bias. JAMA internal medicine, 179(12), 1678-1685. https://doi.org/10.1001/jamainternmed.2019.4122

Witteman, H. (1988). Interpersonal problem solving: Problem conceptualization and communication use. Communications Monographs, 55(4), 336-359. https://doi.org/10.1080/03637758809376176

Zembala, A. (2015). Modele komunikacyjne w relacji lekarz- pacjent. Zeszyty Naukowe Towarzystwa Doktorantów UJ Nauki Ściste, 11(2), 35-50.

\section{Copyrights}

Copyright for this article is retained by the author(s), with first publication rights granted to the journal.

This is an open-access article distributed under the terms and conditions of the Creative Commons Attribution license (http://creativecommons.org/licenses/by/4.0/). 